\title{
Relationships among Cedrus libani, $C$. brevifolia and $C$. atlantica as revealed by the morphological and anatomical needle characters
}

\author{
Anna K. Jasińska $\cdot$ Krystyna Boratyńska • \\ Karolina Sobierajska $\cdot$ Angel Romo $\cdot$ Tolga Ok • \\ Magda Bou Dagher Kharat · Adam Boratyński
}

Received: 9 May 2012/ Accepted: 9 September 2012/Published online: 31 October 2012

(C) The Author(s) 2012. This article is published with open access at Springerlink.com

\begin{abstract}
The main aim of the present study was testing the value of the morphological and anatomical characteristics of the needles in distinguishing Cedrus atlantica, C. libani and C. brevifolia. Nine populations were sampled in their natural habit and 25 characters were used to describe the variation of the brachyblast needles and to analyze the differences between species. The results indicated that morphological and anatomical needle characters provide valuable tools in discrimination of the taxa. The scored differences were statistically significant, as revealed in the Tukey's $t$ test, discrimination analysis and hierarchical analysis of variation. The results support treating C. libani, C. atlantica and C. brevifolia as independent species.
\end{abstract}

Keywords Biometry · Numerical taxonomy · Phytogeography $\cdot$ Plant morphology $\cdot$ Leaf anatomy

A. K. Jasińska $\cdot$ K. Boratyńska · K. Sobierajska ·

A. Boratyński $(\bowtie)$

Institute of Dendrology, Polish Academy of Sciences,

Kórnik, Poland

e-mail: borata@man.poznan.pl

A. Romo

Institute of Botany, Consejo Superior de Investigaciones

Cientificas, Barcelona, Spain

T. Ok

Department of Forest Botany, Kahramanmaraş Sutcu Imam

University, Kahramanmaraş, Turkey

M. Bou Dagher Kharat

Laboratoire «Caractérisation Génomique des Plantes»,

Université Saint-Joseph, Beirut, Lebanon

\section{Introduction}

Cretaceous records on cedar have been described as petrified wood from North-Eastern Asia and North-Western North America (Blokhina and Afonin 2007) and Jurassic records as pollen deposits in northern Asia (Ferguson 1967). This finding supports the North-Eastern Asiatic origin of the genus Cedrus Trew. From four remnant species, three are known from the Mediterranean region [C. atlantica (Endl.) G.Manetti ex Carrière, C. brevifolia (Hook. f.) Henry and C. libani A. Rich], and one from the Himalayan region [C. deodara (Roxb. ex D.Don) G.Don] (Browicz 1982; Greuter et al. 1984; Charco 2001). All these taxa are examples of Tertiary relicts and their ancestors were much widely distributed in Europe, Asia and Africa before the Quaternary (Gaussen 1964; Ferguson 1967; Pons 1998; Magri and Parra 2002; Postigo-Mijarra et al. 2010; Manzi et al. 2011). The reduction of the area of distribution of the genus and formation of disjunctions in its range took place during the late Tertiary as result of climate cooling (Thompson 2005; Utescher et al. 2007; Ivanov et al. 2011). The increasing isolation between the west-, east-Mediterranean and central-Asiatic populations of the cedars was probably a reason for formation of remnant taxa (Gaussen 1964; Pons and Quézel 1985; Pons 1998; Qiao et al. 2007). The Pleistocene climate oscillations were responsible for further reduction of the genus range (Elenga et al. 2000; Svenning 2003; Fady et al. 2008; Terrab et al. 2008; Cheddadi et al. 2009; Postigo-Mijarra et al. 2010). The contemporary distribution of Mediterranean species reflects the overexploitation (Fig. 1), during historical times. In fact, cedar wood was appreciated and used for many purposes such as shipbuilding, temple decoration, construction, furniture, etc. (Khuri et al. 2000; Terrab et al. 2006; Sattout et al. 2007; Fady et al. 2008; Postigo-Mijarra et al. 2010). 


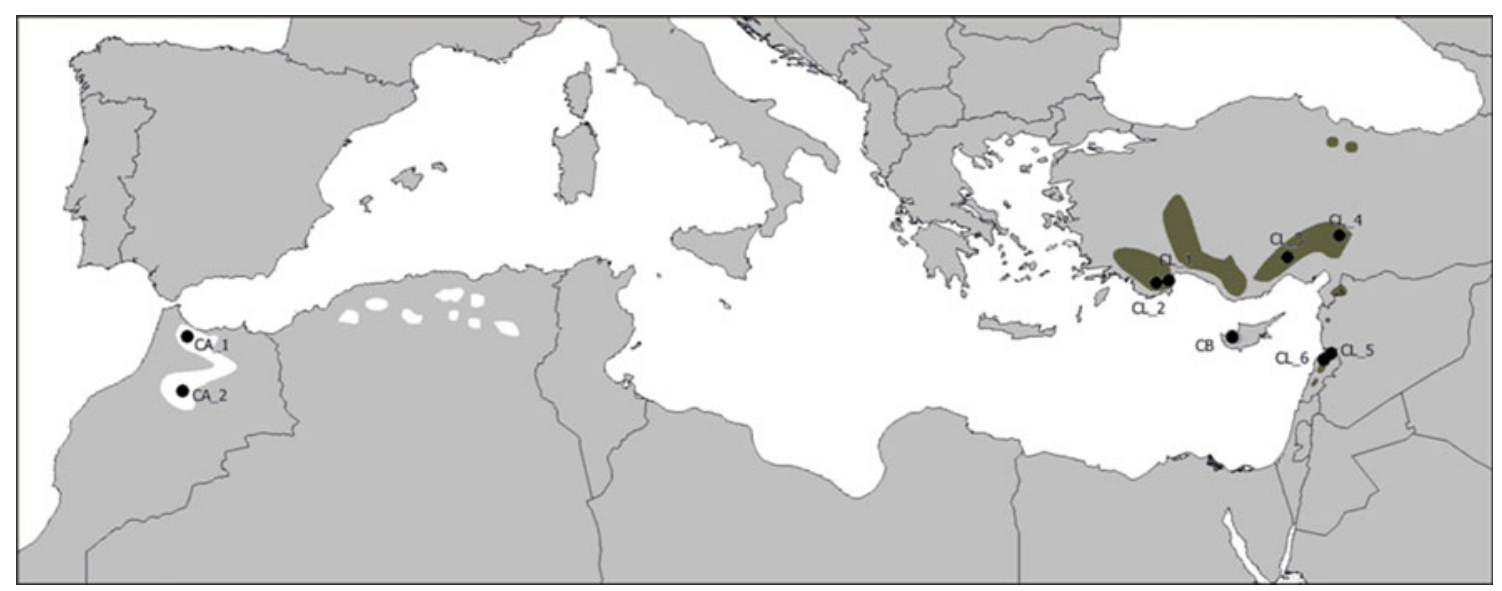

Fig. 1 Geographic ranges of Cedrus atlantica (CA), C. libani (CL) and C. brevifolia (CB) with location of sampled populations (acronyms as in Table 1)

The taxonomic position of the Mediterranean cedars is controversial. This concerns mainly the position of C. brevifolia, endemic to mountains of Cyprus, and C. atlantica from the mountains of north-west Africa. C. brevifolia has been described on the basis of needle and cone characteristics as a variety $C$. libani var. brevifolia Hook. f. and then advanced to the species rank (Gaussen 1964; Page 1990), but more frequently it is treated as subspecies C. libani subsp. brevifolia (Hook. f.) Meikle (Coode and Cullen 1965; Meikle 1977; Greuter et al. 1984; Eckenwalder 2009) or a variety of $C$. libani (Frankis 2000; Farjon 2010). Cedrus atlantica, described originally as Pinus atlantica Endl., then transferred to Cedrus, also was treated as an independent species (Gaussen 1964; Page 1990; Charco 2001; Farjon 2010), as subspecies C. libani A. Rich. subsp. atlantica (Endl.) Batt. et Trab. (Coode and Cullen 1965; Eckenwalder 2009) or variety $C$. libani var. atlantica (Endl.) Hook f.

Distinguished on the basis of the conical crown shape, Cedrus libani, the species among Mediterranean cedars with the largest but segmented geographic range (Browicz 1982; Boydak 2002), was divided into subsp. libani, known from Lebanon mountain ranges and subsp. stenocoma (O. Schwarz) Frankis, which is dispersed in the mountain massifs of Anatolia (Frankis 2000; Farjon 2001; but see also comment by Farjon 2010: 259).

The possibility of hybridization (Fady et al. 2003), together with recent results of cytological (Bou DagherKharrat et al. 2001), isoenzymatic (Scaltsoyiannes 1999), AFLP (Bou Dagher-Kharrat et al. 2007) and cpDNA and mtDNA phylogeny analyses (Qiao et al. 2007) pointed out the close genetic relationships among Mediterranean cedar taxa and suggest for them the subspecific taxonomic rank. The studies on genetic diversity and phylogeography of C. atlantica (Terrab et al. 2006, 2008), genetic diversity of C. libani (Semaan and Dodd 2008) and C. brevifolia
(Eliades et al. 2011) described the high level of genetic variation and significant differences among studied populations of compared species. The Mediterranean cedars differ in respect to the length, width and shape of the male and female cones and in the length of the needles (e.g., Gaussen 1964; Krüssmann 1985; Vidaković 1991; Farjon 2010).

The detailed study on the needle anatomic construction of cedar species is lacking. We hypothesized, that not only length, but also other characteristics of the needles, including anatomic ones vary among Mediterranean species of the genus. The aim of the present study was the comparison of $C$. atlantica, C. brevifolia and C. libani on the material from the natural populations, using biometrical analyses of morphological and anatomical characteristics of the needle.

\section{Materials and methods}

Material for the study was collected in the natural localities of $C$. atlantica in the Rif and Middle Atlas mountains, C. brevifolia in the mountains of Cyprus and C. libani in the Taurus, Antitaurus and Lebanon Mountains (Fig. 1; Table 1). In total nine populations have been sampled by collection of three 2-years old brachyblasts with uninjured, fully developed needles from the insolated part of the crown of 28-30 healthy trees in every population, except for population CA_2, where only ten trees were sampled. The old, cone-bearing trees were sampled at a distance no less than $50 \mathrm{~m}$ from each other. The brachyblasts were conserved in $70 \%$ alcohol and stored at $-20{ }^{\circ} \mathrm{C}$ before sectioning. Every individual tree was represented by ten 1-year-old needles, omitting three first, three last and damaged ones. Needle length (NL) was manually measured and the $2 \mathrm{~mm}$ long section from the central part of every needle were then embedded in the paraplast. The 
Table 1 Studied populations of Cedrus atlantica (CA), C. libani (CL) and C. brevifolia (CB)

\begin{tabular}{|c|c|c|c|c|c|c|}
\hline Species & Location & $\begin{array}{l}\text { No. of } \\
\text { individuals }\end{array}$ & Acronym & Longitude & $\begin{array}{l}\text { Latitude } \\
(\mathrm{N})\end{array}$ & $\begin{array}{l}\text { Altitude } \\
(\mathrm{m})\end{array}$ \\
\hline \multirow[t]{2}{*}{ C. atlantica } & Morocco, Rif Mountains, Jbel Anasan, & 32 & CA_1 & $5.03 \mathrm{~W}$ & 35.01 & 1600 \\
\hline & Marocco, Middle Atlas, S of Azrou & 10 & CA_2 & $5.21 \mathrm{~W}$ & 33.41 & 1750 \\
\hline \multirow[t]{6}{*}{ C. libani } & $\begin{array}{l}\text { Turkey, West Taurus, Gölcük, between } \\
\text { Kemer and Altinyaka }\end{array}$ & 30 & CL_1 & $30.40 \mathrm{E}$ & 36.64 & 1300 \\
\hline & Turkey, West Taurus, Göltarla & 30 & CL_2 & $29.96 \mathrm{E}$ & 36.58 & 1100 \\
\hline & Turkey, Antitaurus, Gülek above Tarsus & 30 & CL_3 & $34.70 \mathrm{E}$ & 37.32 & 1423 \\
\hline & Turkey, Antitaurus, $\mathrm{S}$ of Goksun & 30 & CL_4 & $36.56 \mathrm{E}$ & 37.96 & 1500 \\
\hline & Lebanon, Ehden, Horsh Ehden & 33 & CL_5 & $35.99 \mathrm{E}$ & 34.31 & 1565 \\
\hline & Lebanon, Ammoua (Aakkar) & 33 & CL_6 & $36.26 \mathrm{E}$ & 34.50 & 1743 \\
\hline C. brevifolia & Cyprus, Cedar Valley & 31 & $\mathrm{CB}$ & $32.69 \mathrm{E}$ & 34.99 & 1450 \\
\hline
\end{tabular}

semi-durable anatomic preparations were done following Ruzin's (1999) modified procedure from the slices of $12 \mu \mathrm{m}$ thin, cut using Microtom HM310. The preparations were then photographed under a light microscope Axio Imager A1, using camera AxioCam MRc5. The measurements of the most of the characters (Fig. 2a, b) were conducted on the ten technically best images selected from 25-30 ones for every individual, using AxioVision 4.6. The number of resin canals (NC), of stomata (NS), of fiber cells inside the sclerenchymatous bundle sheath (NSC) and percentages of every of three types of the cells surrounding the resin canals (PSCF, PSCI and PSCT) were counted and/ or estimated for every individual preparation. The shape of the cross-section of vascular bundle (VBS), epidermis cell (ES) and hypodermis cell (HS) were expressed as ratios of length/width. The shape of the needle cross-section is scored in the range of one to seven distinguishable categories (Fig. 2c).

The set of the characters (Table 2) includes those used in the keys to determination of cedars (Gaussen 1964; Maheshwari and Biswas 1970; Krüssmann 1985; Vidaković 1991; Eckenwalder 2009; Marin et al. 2009; Farjon 2010) and detected as discriminating among taxa in the anatomical and morphological examinations of the needle characteristics of pines and firs (Boratyńska and Bobowicz 2001; Boratyńska and Boratyński 2007; Boratyńska and Lewandowska 2009; Dörken and Stützel 2012; Sękiewicz et al. 2012).

\section{Statistical analyses}

To determine the possibility of utilization of multivariate statistical analyses, the frequency distribution of every character was verified using the Shapiro-Wilk test. Every metrical and estimated character was standardized, and the percentage of different types of fibrous cells around resin canals were arcsine transformed prior to analyses (Stanisz 2007).

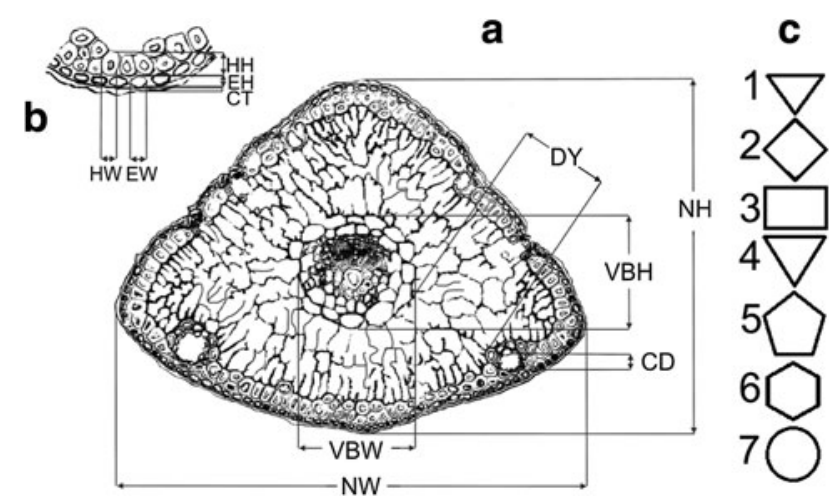

Fig. 2 Measured and estimated characters of the needle cross-section (a), cuticle, epidermis and hypodermis (b) the character acronyms as in Table 2 and (c) cross-section shape categories (1-7, the most common types)

The statistic value of every character for differentiation between species was verified in a post hoc RIR Tukey and Kruskal-Wallis test for characters NC, PSCF, PSCI and PSCT. The discrimination power of a particular character was determined in discrimination analysis. The relations among populations of particular taxa were estimated on the scatter-plot of the discrimination function on the space between the first discrimination variables, after stepwise discrimination analysis on the whole set of characters (Tabachnik and Fidell 1996; Sokal and Rohlf 1997). The Euclidean distances among populations were estimated using all characters except for ratios, and agglomeration of populations on the shortest Euclidean distances according Ward's method were analyzed to verify the relations between taxa revealed by discrimination analysis. The hierarchical analysis of variance was applied to estimate the percentages of variation of every character, which differ between species and between populations within species (Sokal and Rohlf 1997). Statistica PL 9.0 for Windows (StatSoft PL) and JMP 9 (SAS Inc.) were used for calculations. 
Table 2 Average values (mean), variation coefficient $(V)$, discrimination power testings ( $\lambda$ partial $\lambda$ value, $P$ significance of $\lambda$ ) and significance $(* * P \geq 0.01 ; * P \geq 0.05)$ of differences between analyzed characters of needles of Cedrus atlantica, C. libani and C. brevifolia detected in Tukey's $t$ test and/or Kruskal-Wallis test (for explanation see also Fig. 2)

\begin{tabular}{|c|c|c|c|c|c|c|c|c|c|c|c|c|}
\hline \multirow[t]{2}{*}{ Character } & \multirow[t]{2}{*}{ Acronym } & \multicolumn{2}{|c|}{ C. atlantica $\mathrm{CA}$} & \multicolumn{2}{|c|}{ C. libani $\mathrm{CL}$} & \multicolumn{2}{|c|}{$\begin{array}{l}\text { C. brevifolia } \\
\mathrm{CB}\end{array}$} & \multicolumn{2}{|c|}{$\begin{array}{l}\text { Discrimination } \\
\text { between } \\
\text { species }\end{array}$} & \multicolumn{3}{|c|}{$\begin{array}{l}\text { Tukey's } t \text { test } \\
\text { and Kruskal- } \\
\text { Wallis test }\end{array}$} \\
\hline & & Mean & $V$ & Mean & $V$ & Mean & $V$ & $\lambda$ & $P$ & $\begin{array}{l}\mathrm{CA} / \\
\mathrm{CL}\end{array}$ & $\begin{array}{l}\mathrm{CA} / \\
\mathrm{CB}\end{array}$ & $\begin{array}{l}\mathrm{CL} / \\
\mathrm{CB}\end{array}$ \\
\hline Needle length (mm) & NL & 13.30 & 13.69 & 16.73 & 17.23 & 9.81 & 20.84 & 0.869 & 0.000 & $* *$ & $* *$ & $* *$ \\
\hline Width of needle cross-section $(\mu \mathrm{m})$ & NW & 834.89 & 12.14 & 885.16 & 10.26 & 910.89 & 11.64 & 0.966 & 0.029 & $* *$ & $* *$ & - \\
\hline Height of needle cross-section $(\mu \mathrm{m})$ & $\mathrm{NH}$ & 772.27 & 9.06 & 801.19 & 10.19 & 820.06 & 9.42 & 0.950 & 0.005 & - & - & - \\
\hline $\begin{array}{l}\text { Width of vascular bundle including } \\
\text { endodermis }(\mu \mathrm{m})\end{array}$ & VBW & 307.97 & 12.52 & 337.23 & 11.06 & 317.82 & 15.93 & 0.998 & 0.852 & $* *$ & - & - \\
\hline $\begin{array}{l}\text { Height of vascular bundle including } \\
\text { endodermis }(\mu \mathrm{m})\end{array}$ & $\mathrm{VBH}$ & 282.09 & 11.44 & 302.83 & 11.03 & 288.49 & 14.55 & 0.939 & 0.001 & $* *$ & - & - \\
\hline $\begin{array}{l}\text { Distance between resin canal and } \\
\text { vascular bundle }(\mu \mathrm{m})\end{array}$ & DY & 154.09 & 17.81 & 141.60 & 24.82 & 124.57 & 24.29 & 0.934 & 0.000 & - & $* *$ & - \\
\hline Diameter of resin canal $(\mu \mathrm{m})$ & $\mathrm{CD}$ & 60.30 & 21.47 & 60.29 & 25.82 & 102.34 & 24.86 & 0.897 & 0.000 & - & $* *$ & $* *$ \\
\hline Number of resin canals & $\mathrm{NC}$ & 1.28 & 37.27 & 1.26 & 32.48 & 0.78 & 50.91 & 0.915 & 0.000 & - & $* *$ & $* *$ \\
\hline Height of epidermis cell layer $(\mu \mathrm{m})$ & $\mathrm{EH}$ & 20.86 & 6.35 & 19.77 & 8.89 & 19.33 & 7.86 & 0.971 & 0.048 & $* *$ & $* *$ & - \\
\hline Height of hypodermis cell layer $(\mu \mathrm{m})$ & $\mathrm{HH}$ & 30.47 & 13.48 & 21.76 & 12.57 & 24.55 & 11.36 & 0.853 & 0.000 & $* *$ & $* *$ & $* *$ \\
\hline Cuticle thickness $(\mu \mathrm{m})$ & $\mathrm{CT}$ & 0.92 & 16.97 & 0.81 & 21.31 & 0.71 & 13.97 & 0.995 & 0.572 & - & - & $*$ \\
\hline Width of epidermis cell layer $(\mu \mathrm{m})$ & EW & 20.78 & 7.96 & 18.72 & 8.86 & 17.84 & 9.26 & 0.960 & 0.015 & $* *$ & $* *$ & $*$ \\
\hline Width of hypodermis cell layer $(\mu \mathrm{m})$ & HW & 25.68 & 10.21 & 22.45 & 10.59 & 24.33 & 8.76 & 0.911 & 0.000 & $* *$ & $*$ & $* *$ \\
\hline Number of stomata in cross-section & NS & 7.47 & 14.96 & 9.39 & 14.56 & 8.68 & 16.97 & 0.947 & 0.003 & $* *$ & $* *$ & $*$ \\
\hline $\begin{array}{l}\text { Number of sclerenchyma cells inside } \\
\text { the vascular bundle }\end{array}$ & NSC & 7.97 & 33.01 & 14.73 & 29.06 & 7.31 & 50.59 & 0.956 & 0.009 & $* *$ & - & $* *$ \\
\hline \multicolumn{13}{|l|}{$\begin{array}{l}\text { Percentage of sclerenchyma cells } \\
\text { around resin canal: }\end{array}$} \\
\hline $\begin{array}{l}\text { Fiber cells with thick walls and } \\
\text { restricted lumen }(\%)\end{array}$ & PSCF & 30.89 & 54.70 & 27.99 & 65.33 & 5.74 & 153.64 & 0.989 & 0.324 & - & $* *$ & $* *$ \\
\hline $\begin{array}{l}\text { Fibrous cells with intermediate thick } \\
\text { walls }(\%)\end{array}$ & PSCI & 54.09 & 42.53 & 63.00 & 30.06 & 17.32 & 98.83 & 0.993 & 0.465 & - & $* *$ & $* *$ \\
\hline $\begin{array}{l}\text { Cells with thin walls and wide } \\
\text { lumens }(\%)\end{array}$ & PSCT & 15.02 & 118.39 & 8.86 & 142.89 & 78.02 & 23.11 & 0.625 & 0.000 & $*$ & $* *$ & $* *$ \\
\hline $\begin{array}{l}\text { Shape of vascular bundle cross-section } \\
\text { (VBW/VBH) }\end{array}$ & VBS & 1.09 & 3.34 & 1.12 & 4.40 & 1.10 & 4.46 & 0.987 & 0.268 & - & - & - \\
\hline Shape of epidermis cell $(\mathrm{EH} / \mathrm{EW})$ & ES & 1.02 & 8.95 & 1.07 & 8.06 & 1.10 & 9.00 & 0.997 & 0.749 & - & $*$ & - \\
\hline Shape of hypodermis cell $(\mathrm{HH} / \mathrm{HW})$ & HS & 1.20 & 11.78 & 0.98 & 11.36 & 1.03 & 13.38 & 0.925 & 0.000 & $* *$ & $* *$ & - \\
\hline Shape of needle (NL/NW) & $\mathrm{SN}$ & 16.34 & 18.97 & 19.26 & 21.40 & 11.00 & 19.07 & 0.998 & 0.794 & $* *$ & $* *$ & $* *$ \\
\hline $\begin{array}{l}\text { Proportion of needle/vascular bundle } \\
\text { width (NW/VBW) }\end{array}$ & PNVB & 2.73 & 6.16 & 2.64 & 7.12 & 2.90 & 7.59 & 0.969 & 0.033 & - & $* *$ & $* *$ \\
\hline $\begin{array}{l}\text { Proportion of needle width/resin canal } \\
\text { diameter (NW/CD) }\end{array}$ & PNRC & 15.21 & 17.76 & 16.06 & 18.46 & 10.50 & 36.64 & 0.917 & 0.000 & - & $* *$ & $* *$ \\
\hline $\begin{array}{l}\text { Proportion of vascular bundle width/ } \\
\text { resin canal diameter (VBW/CD) }\end{array}$ & PVBRC & 5.56 & 20.22 & 6.08 & 21.31 & 3.53 & 40.43 & 0.992 & 0.410 & - & $* *$ & $* *$ \\
\hline
\end{tabular}

\section{Results}

\section{Evaluation of characters}

The average values of particular characters with ranges of oscillation and variation coefficients for every population were calculated and compared (Table 3). The highest values of variation coefficient were detected for percentages of cells around resin canals types (PSCF, PSCI and PSCT). Slightly lower $V$-values had also a number of the fibrous cells inside the vascular bundle and a number of resin canals (NSC and NC, respectively). The value of variation 


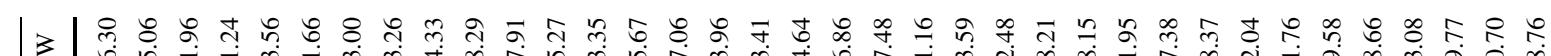

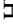

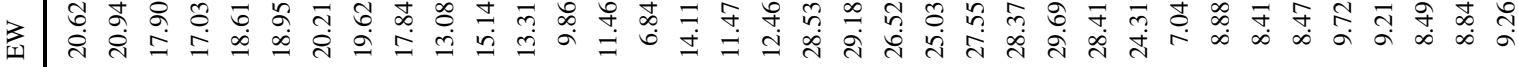

†

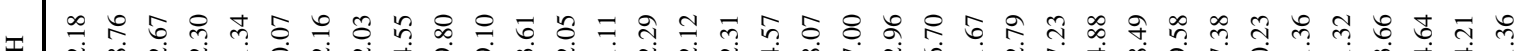

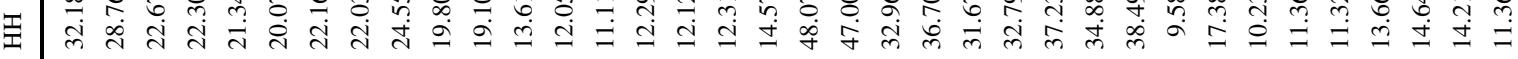

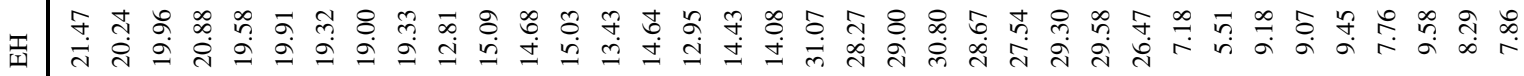

Z

ด 둥

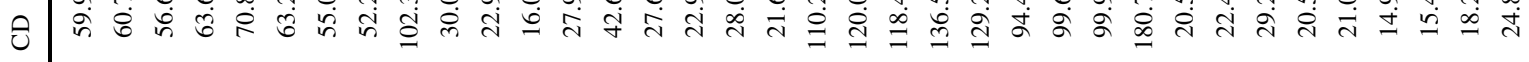

我

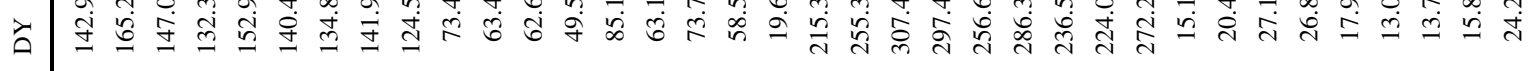

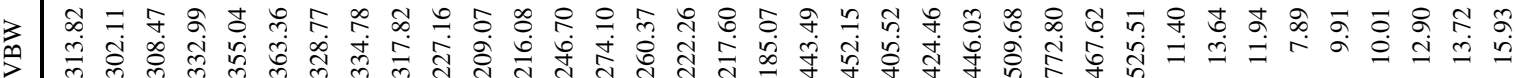

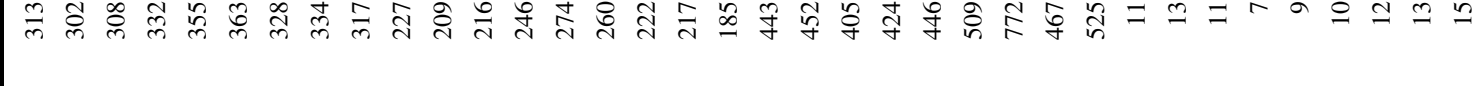

$\infty$ 유 8 o

ही

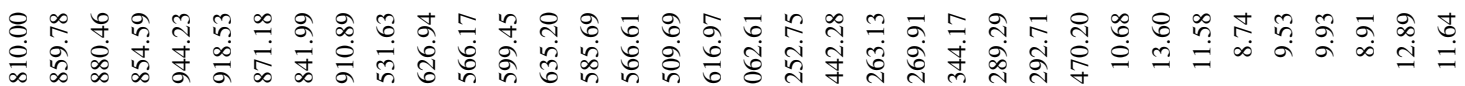

m $\infty$ m

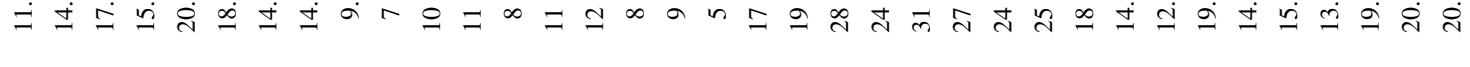

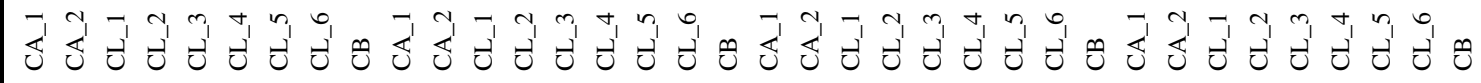

言 


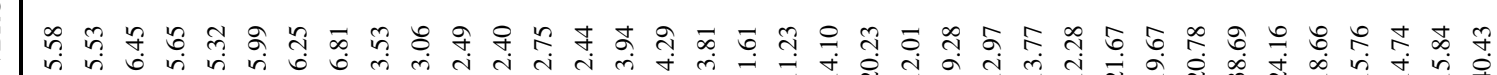

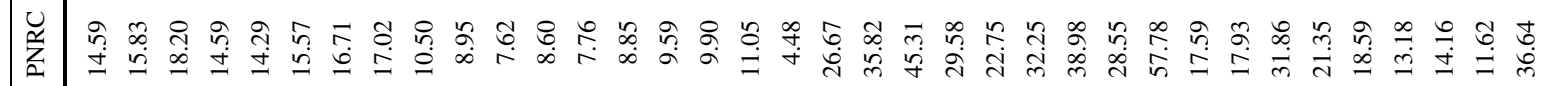

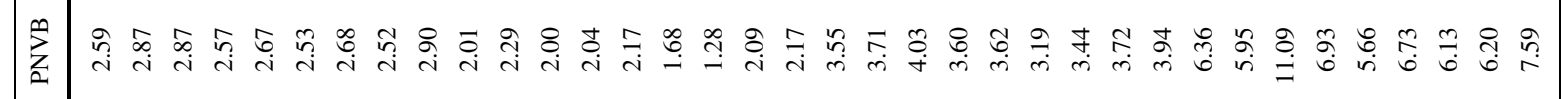

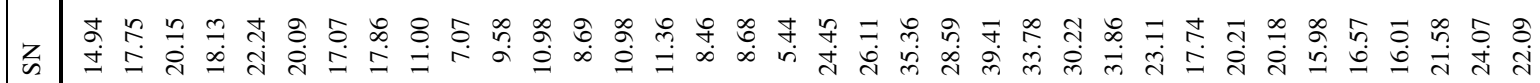

ص

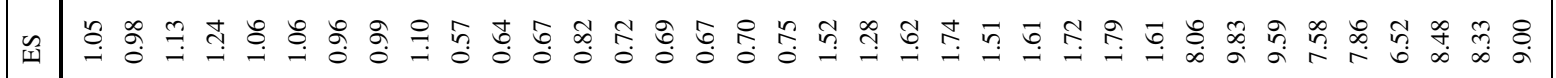

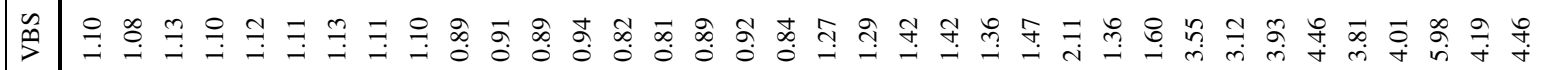

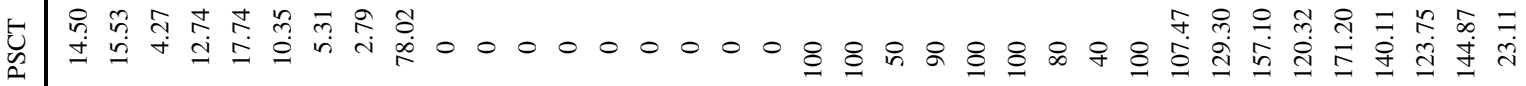

ए

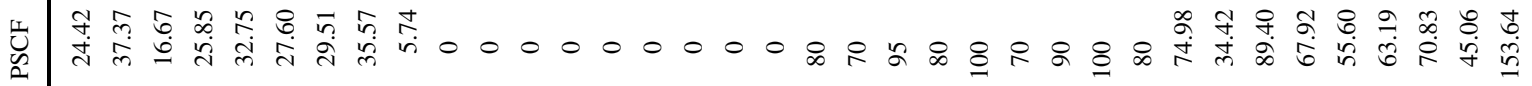

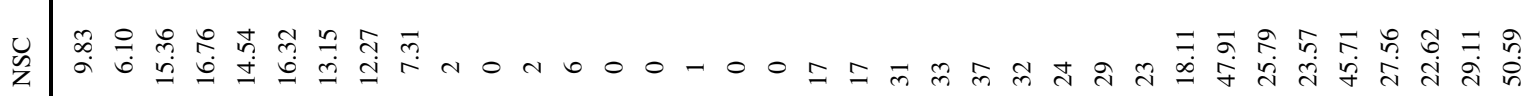

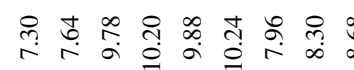

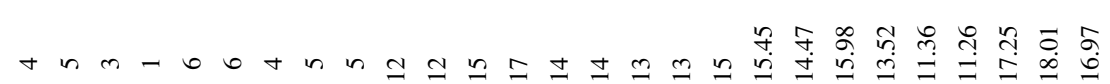

है

总



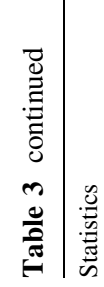

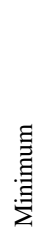

竞

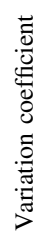


Table 4 Values of Pearson's correlation coefficients between characters of needles of Cedrus altantica, C. libani and C. brevifolia; character acronyms as in Table 2

\begin{tabular}{|c|c|c|c|c|c|c|c|c|c|c|c|c|c|c|c|c|c|}
\hline & NL & NW & $\mathrm{NH}$ & VBW & $\mathrm{VBH}$ & DY & $\mathrm{CD}$ & $\mathrm{NC}$ & EH & $\mathrm{HH}$ & CT & EW & HW & NS & $\mathrm{NSC}$ & PSCF & PSCI \\
\hline NW & 0.21 & & & & & & & & & & & & & & & & \\
\hline $\mathrm{NH}$ & 0.12 & 0.66 & & & & & & & & & & & & & & & \\
\hline VBW & 0.24 & 0.76 & 0.73 & & & & & & & & & & & & & & \\
\hline VBH & 0.21 & 0.69 & 0.81 & 0.94 & & & & & & & & & & & & & \\
\hline DY & 0.24 & 0.43 & 0.46 & 0.31 & 0.33 & & & & & & & & & & & & \\
\hline $\mathrm{CD}$ & -0.25 & 0.42 & 0.30 & 0.16 & 0.18 & -0.13 & & & & & & & & & & & \\
\hline $\mathrm{NC}$ & 0.17 & 0.17 & -0.11 & 0.08 & 0.03 & -0.02 & -0.16 & & & & & & & & & & \\
\hline $\mathrm{EH}$ & -0.10 & 0.05 & 0.23 & 0.16 & 0.16 & 0.06 & 0.04 & -0.09 & & & & & & & & & \\
\hline $\mathrm{HH}$ & $-\mathbf{0 . 3 3}$ & -0.08 & 0.02 & -0.11 & -0.10 & 0.10 & 0.12 & -0.05 & 0.34 & & & & & & & & \\
\hline $\mathrm{CT}$ & 0.21 & 0.20 & 0.24 & 0.24 & 0.23 & 0.23 & -0.02 & 0.11 & -0.02 & -0.01 & & & & & & & \\
\hline EW & -0.12 & 0.05 & 0.15 & 0.10 & 0.08 & 0.26 & -0.13 & 0.02 & 0.38 & 0.39 & 0.28 & & & & & & \\
\hline HW & -0.20 & 0.14 & 0.22 & 0.08 & 0.08 & 0.25 & 0.15 & -0.13 & 0.25 & 0.62 & 0.20 & 0.59 & & & & & \\
\hline NS & 0.35 & 0.56 & 0.55 & 0.59 & 0.62 & 0.28 & 0.16 & -0.01 & 0.05 & -0.34 & 0.05 & -0.32 & -0.26 & & & & \\
\hline NSC & 0.47 & 0.20 & 0.20 & 0.35 & 0.31 & 0.06 & -0.27 & 0.15 & 0.00 & -0.33 & -0.05 & -0.19 & -0.34 & 0.40 & & & \\
\hline PSCF & 0.23 & -0.02 & 0.08 & 0.06 & 0.06 & 0.14 & -0.22 & 0.04 & -0.11 & 0.06 & 0.24 & 0.15 & 0.07 & -0.03 & 0.23 & & \\
\hline PSCI & 0.20 & -0.08 & -0.08 & 0.04 & 0.01 & 0.12 & -0.52 & 0.22 & 0.16 & -0.17 & -0.09 & 0.08 & -0.17 & 0.07 & 0.33 & -0.24 & \\
\hline PSCT & -0.35 & 0.09 & 0.03 & -0.07 & -0.05 & -0.20 & 0.63 & -0.22 & -0.06 & 0.12 & -0.07 & -0.17 & 0.11 & -0.05 & -0.46 & -0.46 & -0.74 \\
\hline
\end{tabular}

Bold values indicate statistically significant at $p=0.01$

coefficient below $10 \%$ was characteristic for $\mathrm{EH}, \mathrm{EW}, \mathrm{ES}$, VBS and in the most of the populations for $\mathrm{HW}, \mathrm{NH}$, and PNVB (Table 3).

The metric characters of the needle and vascular bundle were generally dependent for each other (Table 4). The highest positive correlations were detected between dimensions of the needle ( $\mathrm{NW}$ and $\mathrm{NH}$ ), dimensions of the vascular bundle (VBH and VBW) and both these character sets (Table 4). The dimensions of the hypodermis cell ( $\mathrm{HH}$ and HW) and width of hypodermis and epidermis cell correlated positively (HW and EW), the number of stomata with the dimensions of the needle and vascular bundle (NS, $\mathrm{NW}, \mathrm{NH}, \mathrm{VBW}$ and $\mathrm{VBH}$ ) and percentage of thick-wall cells around resin canals with diameter of resin canals (PSCT and CD) are also correlated with each other. The matrices of Pearson's correlation coefficients for C. libani, $C$. atlantica and $C$. brevifolia showed the highest number of statistically significant connections $(P<0.05)$ within the first and lowest within the last species, 55, 37 and $21 \%$, respectively.

Intra-population variation

The level of differentiation of individuals within each of the nine tested populations is comparable independent of taxon, except for CA_2 represented by only ten individuals. It is especially interesting, that the level of variation in C. brevifolia was similar to the variable populations of
C. libani. The populations of the latter species from the Lebanon Mountains revealed a relatively low level of differentiation among individuals, in spite of comparable values of the variation coefficient (Table 3).

The differentiation of individuals within particular populations was determined mostly by such characters, as $\mathrm{NW}$ and $\mathrm{NH}$, then $\mathrm{VBW}$ and $\mathrm{VBH}, \mathrm{NL}, \mathrm{PSCF}, \mathrm{PSCI}$, PSCT, NSC and NS. Among these characters the NW, NH, $\mathrm{VBW}$ and $\mathrm{VBH}$ were found as relatively stable with a low level of variation coefficient, but NL, PSCF, PSCI, PSCT, NSC and NS were inversely related to the variables and even were the most variable ones (Tables 2, 3).

Differentiation of populations

The Tukey's test for characters with a normal and a Kruskal-Wallis test for those of biased distribution (NC, PSCF, PSCI and PSCT) revealed, that among all compared populations at least two characters separate them at statistically significant level $(P \leq 0.01)$. The NL, NSC, NS, ES and CT differentiating among highest numbers of populations (Table 5).

The length of particular needles (NL) on every dwarf shoot differed strongly not only within individuals of every compared population but also among $72 \%$ of possible pair-wise comparisons of populations. The needles of C. brevifolia were $9.8 \mathrm{~mm}$ long in average, varying between 5 and $18 \mathrm{~mm}$ (Tables 2, 3), those of $C$. libani were 


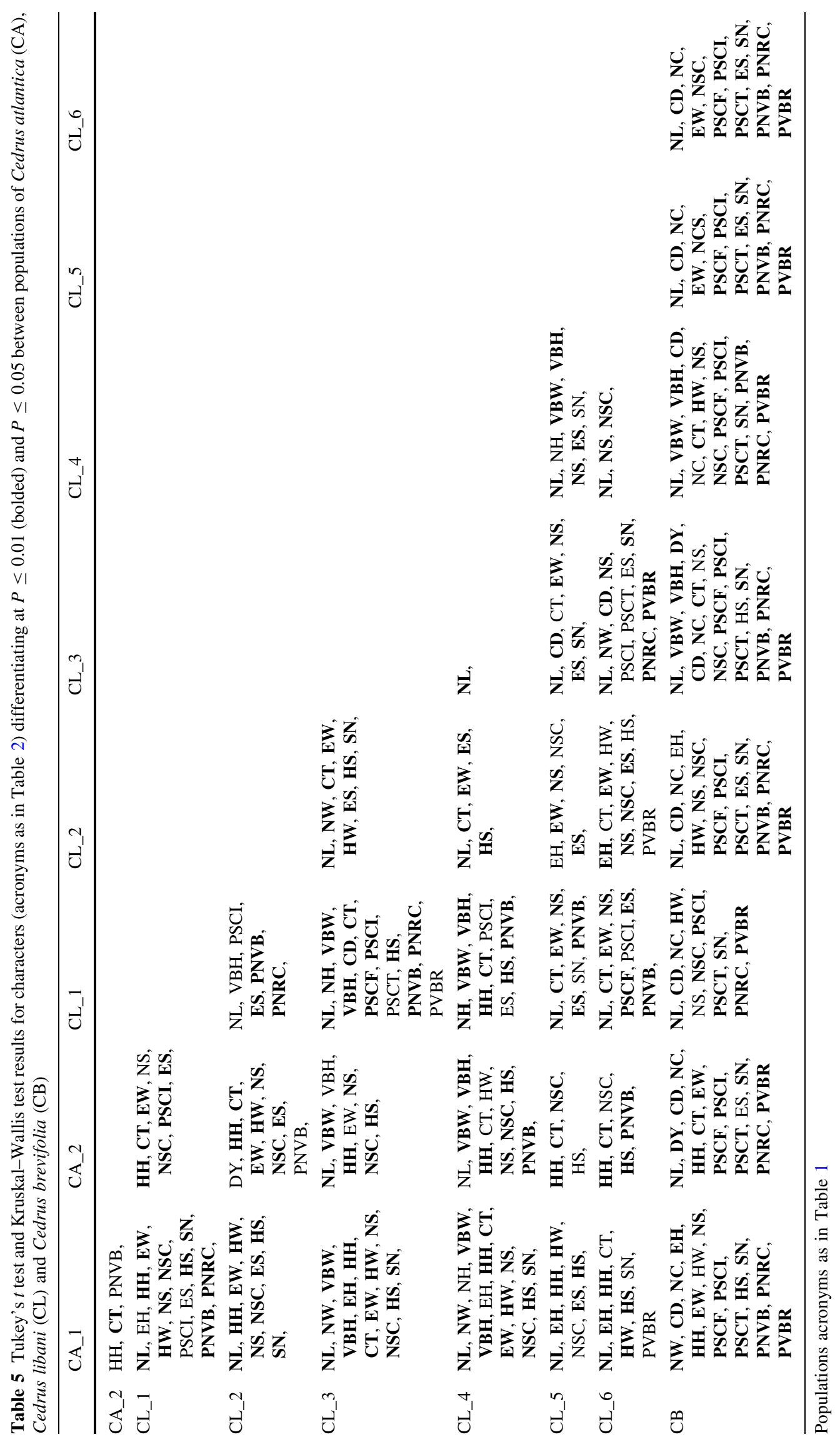






b

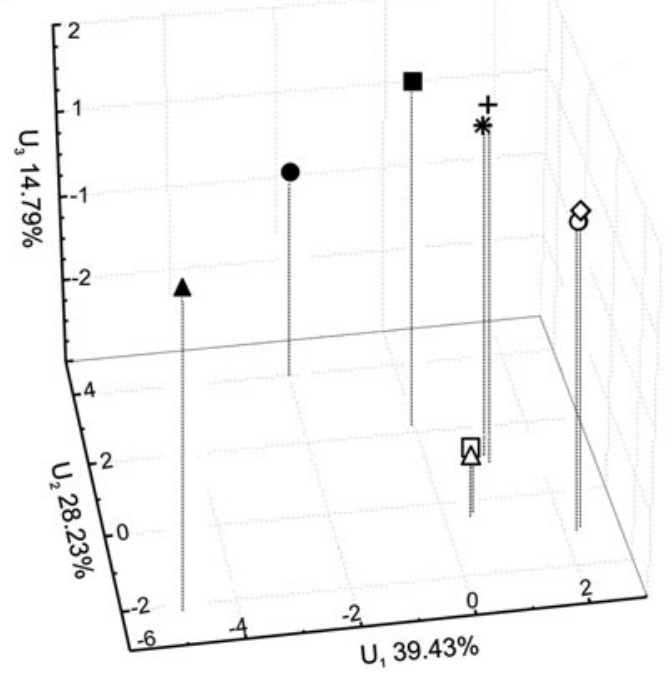

Fig. 3 Results of discrimination analyses: a dispersion of individuals of Cedrus atlantica (CA), C. libani (CL) and C. brevifolia (CB) on the space among the two first discrimination variables; $\mathbf{b}$ dispersion of populations of $C$. atlantica (filled square $\mathrm{CL} \_1$, filled circle $\mathrm{CL} \_2$ ), C. libani (plus $\mathrm{CL} \_1$, asterisk $\mathrm{CL}$ 2, open diamond $\mathrm{CL} \_3$, open circle CL_4, open square CL_5, open triangle CL_6) and C. brevifolia (filled triangle) (population acronyms as in Table 1) in the space among three first discrimination variables

$16.7 \mathrm{~mm}$ in average, ranging between 8 and $31 \mathrm{~mm}$, with the shortest needles in populations from the Lebanon Mountains. The NL of $C$. atlantica was intermediate between those of $C$. libani and $C$. brevifolia.

The highest values of NW, NH, VBW and VBH were found in $C$. libani (CL_3 and CL_4), while the lowest in C. atlantica (CA_2), nevertheless the absolute minima and maxima of these characters were detected in C. brevifolia. The highest average value of $\mathrm{CD}$ was characteristic for C. brevifolia, lowest for $C$. libani (Table 2). The absolute minimal values of these characters were detected in the same taxa, while the maximal ones in $C$. libani populations CL_1 and CL_5. The extremely wide resin canals were observed in $C$. brevifolia, but the average number of them (NC) was lower, when compare to other cedar taxa (Table 2; Fig. 3).

The dimensions and proportions of the epidermis cells (EH, EW and ES) were similar in every compared population and taxon and did not differentiate them. The average values of CT were also very close in compared populations and taxa, except of $C$. atlantica from Middle Atlas (CA_2), which had the thickest cuticle (Table 3). Similarly, the highest average values of dimensions and proportions of hypodermis cells $(\mathrm{HH}$, HW and HS) were detected in C. atlantica. The populations of $C$. libani and $C$. brevifolia had HS close to 1 (Table 3).

The number of stomata detected on the needle crosssection (NS) ranged between 1 and 17, 9 in average for whole genus, but was higher in $C$. libani and lower in C. atlantica and C. brevifolia (Table 2). Within populations of $C$. libani, the populations sampled from the Taurus Mountains had about 10 stomata on average, while those from the Lebanon Mountains only about 8.5 on average (Table 3).

Cedrus brevifolia had resin canals surrounded with mainly thin-wall cells (PCST), inversely as in the two other compared species. Inside the vascular bundle of C. libani 15 fibrous cells (NSC) were detected on average, while in C. atlantica and C. brevifolia only 8 and 7 cells were counted, respectively (Table 3 ).

Among seven general types of the needle cross-section (Fig. 2c), the most common were pentagonal, triangular and rhomboidal (types 5, 1 and 2, respectively). In spite of that, this character did not differ nor for individuals within populations, and neither for populations within taxa.

\section{Taxonomical differences}

The Tukey's test and Kruskal-Wallis test showed that only the values of NH and VBS did not differ at a statistically significant level among species studied, while all other characters could be used in separation of species at least between two of them with $P \leq 0.05$ (Table 2). Between three possible combinations of compared species, NL, HH and SN differentiated at $P \leq 0.01$ and, additionally, EW, HW and NS with $0.05 \leq P \leq 0.01$. All other characters vary between two combinations (Table 2).

The analysis of discrimination function revealed, that 13 of 25 tested characters of the cedar needles had high discriminating power among taxa $(P \leq 0.01)$ and another four discriminate with $P \leq 0.05$ (Table 2). The dispersion of individuals on the space between the two first canonical values $U_{1}$ and $U_{2}$ (responsible for $100 \%$ of the variation among species) demonstrated three dispersed "clouds" of single trees, representing three compared species (Fig. 3a). 
The canonical variable $U_{1}$ was determined mostly by PSCT, CD, NL, NSC, while the $U_{2}$ by HH. It is noteworthy, that all individuals of $C$. brevifolia are inside the $95 \%$ confidence interval and did not enter, neither area delimited by the confidence interval of $C$. libani individuals, nor of C. atlantica (Fig. 3a). The individuals of the latter two species are partly intermingling, also two individuals of C. libani, both from anti Atlas population CL 3, entered the confidential area of $C$. brevifolia.

Dispersion of centroids of populations, in this case among three canonical variables $U_{1}, U_{2}$ and $U_{3}$, responsible for more than $85 \%$ of the total variation among populations, confirming the high level of multivariate difference of $C$. brevifolia population from all other populations (Fig. 3b). On the same scatter plot, the separation of $C$. atlantica from C. libani populations was well marked. The differences between two populations of $C$. atlantica appeared to be high, but CA_2 is represented by only ten individuals, which can influence this result.

The six populations of $C$. libani formed three geographic groups, CL_1 and CL_2 from the West Taurus, CL_3 and CL_4 from the Antitaurus and CL_5 and CL_6 from the Lebanon Mountains (Fig. 3b). Most of the mentioned populations were well discriminated by the first and second canonical variables, only those sampled from the West Taurus mountains are significantly differentiated also by $U_{3}$. The $U_{1}$, responsible for about $40 \%$ of variation, was determined mostly by PSCT, NL, SN, HH, CD and NSC, while $U_{2}$, bearing about $29 \%$ of information on the total variation, was correlated mostly to $\mathrm{HH}, \mathrm{PSCT}, \mathrm{CD}$ and NS, $U_{3}$ responsible for about $15 \%$ of the total detected variation, is determined by ES and CT. The matrix of discrimination classification indicate the $100 \%$ of correct classification of individuals to the populations of $C$. atlantica and to C. brevifolia, but $62-83 \%$ of correct classification of individuals to particular populations of C. libani. The variation ranges of the populations of the latter species were partly overlapping.

The agglomeration of populations on the shortest Euclidean distances indicated a higher level of difference of Cypriote C. brevifolia (Fig. 4), when compare to populations of $C$. libani, than to $C$. atlantica. The differentiation of populations of $C$. atlantica and $C$. libani confirmed taxonomic differences between them, but also revealed geographic differentiation of six populations of the latter. The populations of $C$. libani sampled in the Lebanon Mountains appeared closest to each other and different from those from the West Taurus and Antitaurus Mountains (Fig. 4), as it was detected in the discrimination analysis (Fig. 3b).

The hierarchical analysis of variance showed, that species were differentiated at the highest significance $(P>0.01)$ by $\mathrm{CD}, \mathrm{HH}$, NSC, PSCI, PSCT and PVBRC. Statistically significant at a lower level $(0.01>P>0.05)$

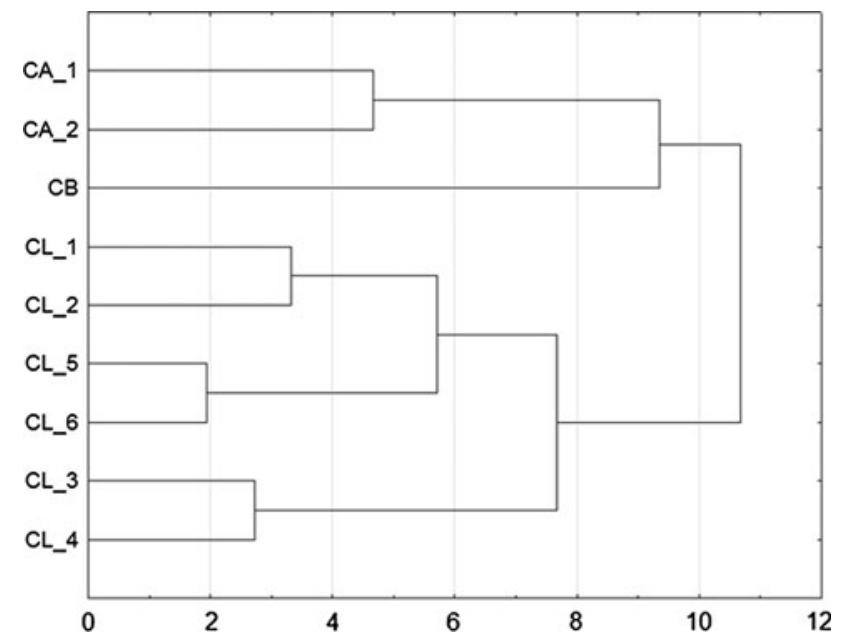

Fig. 4 Relations among populations of Cedrus atlantica, C. libani and $C$. brevifolia (acronyms of populations as in Table 1) on the shortest Euclidean distances obtained from leaf anatomical characteristic of the brachyblasts

were also HW, HS, NC, PSCF, SN and PNRC (Table 6). The populations within species differentiated at a statistically significant level for all characters except for $\mathrm{NC}$ and VBS, while individuals within populations differed at a statistically significant level in respect to all analyzed characters.

\section{Discussion}

\section{Differences between species}

Among the analyzed set of characters of needles only NL (partly also $\mathrm{NW}$ and $\mathrm{NH}$ ) were used to discriminate C. atlantica, C. libani, C. brevifolia and C. deodara (Gaussen 1964; Maheshwari and Biswas 1970; Farjon 2010; Vidaković 1991; Brunetti et al. 2001). Unfortunately, only Farjon (2010) indicated the origin of the needles described by him from the long shoots. The long shoot needles are generally longer than those of brachyblasts, which are used in the present study. The average NL for every studied species (Tables 2,3) seem to be shorter, with ranges of this character either smaller or comparable to those in the published sources. The average values for NL of $C$. atlantica were detected as $13.3 \mathrm{~mm}$, ranging between 7 and $19 \mathrm{~mm}$. Those values are smaller than 1-2.5 (3) $\mathrm{cm}$ reported by Gaussen (1964) and Farjon (2010). The average NL of C. libani, found in our study was $16.7 \mathrm{~mm}$ and ranging between 8 and $31 \mathrm{~mm}$, can be compared to the data of Vidaković (1991) and Farjon (2010). The C. brevifolia average NL detected as $9.8 \mathrm{~mm}$ (ranging between 5 and $18 \mathrm{~mm}$ ), is also comparable to those reported earlier (Gaussen 1964; Vidaković 1991; Farjon 2010). 
Table 6 Hierarchical analysis of variance based on the needle traits

\begin{tabular}{|c|c|c|c|c|c|}
\hline Character & Variance component & $d f$ & $F$ & Percent of variation & $P$ \\
\hline \multirow[t]{3}{*}{$\mathrm{CD}$} & Between species & 2 & 22.24 & 53.34 & 0.001 \\
\hline & Between populations of certain species & 6 & 5.99 & 4.33 & 0.000 \\
\hline & Between individuals of certain population & 233 & 3.08 & 15.01 & 0.000 \\
\hline \multirow{3}{*}{$\mathrm{NC}$} & Between species & 2 & 13.47 & 9.67 & 0.004 \\
\hline & Between populations of certain species & 6 & 1.30 & 0.34 & 0.258 \\
\hline & Between individuals of certain population & 237 & 1.82 & 13.36 & 0.000 \\
\hline \multirow{3}{*}{$\mathrm{HH}$} & Between species & 2 & 30.77 & 47.66 & 0.001 \\
\hline & Between populations of certain species & 6 & 4.28 & 2.47 & 0.000 \\
\hline & Between individuals of certain population & 237 & 2.41 & 11.56 & 0.000 \\
\hline \multirow{3}{*}{ HW } & Between species & 2 & 7.17 & 15.38 & 0.024 \\
\hline & Between populations of certain species & 6 & 4.58 & 3.94 & 0.000 \\
\hline & Between individuals of certain population & 237 & 2.04 & 14.62 & 0.000 \\
\hline \multirow[t]{3}{*}{ NSC } & Between species & 2 & 13.55 & 37.81 & 0.005 \\
\hline & Between populations of certain species & 6 & 5.54 & 4.93 & 0.000 \\
\hline & Between individuals of certain population & 237 & 3.43 & 20.21 & 0.000 \\
\hline \multirow[t]{3}{*}{ PSCF } & Between species & 2 & 5.14 & 16.54 & 0.044 \\
\hline & Between populations of certain species & 6 & 4.93 & 6.46 & 0.000 \\
\hline & Between individuals of certain population & 232 & 3.02 & 28.35 & 0.000 \\
\hline \multirow[t]{3}{*}{ PSCI } & Between species & 2 & 11.49 & 39.32 & 0.007 \\
\hline & Between populations of certain species & 6 & 7.26 & 6.67 & 0.001 \\
\hline & Between individuals of certain population & 232 & 2.52 & 16.42 & 0.000 \\
\hline \multirow[t]{3}{*}{ PSCT } & Between species & 2 & 67.43 & 70.29 & 0.000 \\
\hline & Between populations of certain species & 6 & 3.57 & 1.51 & 0.002 \\
\hline & Between individuals of certain population & 232 & 2.82 & 9.71 & 0.000 \\
\hline \multirow[t]{3}{*}{ HS } & Between species & 2 & 6.36 & 19.26 & 0.032 \\
\hline & Between populations of certain species & 6 & 7.64 & 6.37 & 0.000 \\
\hline & Between individuals of certain population & 237 & 1.87 & 11.61 & 0.000 \\
\hline \multirow[t]{3}{*}{ SN } & Between species & 2 & 10.31 & 43.01 & 0.011 \\
\hline & Between populations of certain species & 6 & 8.61 & 8.31 & 0.000 \\
\hline & Between individuals of certain population & 235 & 5.32 & 23.30 & 0.000 \\
\hline \multirow[t]{3}{*}{ PNRC } & Between species & 2 & 6.54 & 20.56 & 0.028 \\
\hline & Between populations of certain species & 6 & 5.88 & 6.36 & 0.000 \\
\hline & Between individuals of certain population & 233 & 2.30 & 18.66 & 0.000 \\
\hline \multirow[t]{3}{*}{ PVBRC } & Between species & 2 & 11.51 & 26.63 & 0.007 \\
\hline & Between populations of certain species & 6 & 3.92 & 3.83 & 0.001 \\
\hline & Between individuals of certain population & 233 & 2.57 & 20.40 & 0.000 \\
\hline
\end{tabular}

Character acronyms as in Table 2

$d f$ Degrees of freedom, $F$ statistic value

Needles shorter than those detected for three species in the present study were reported from the fossils of Tertiary cedars (Gaussen 1964; Velitzelos et al. 2000). On that background $C$. brevifolia was believed to conserve the most ancestral type of the needle, while $C$. deodara, which has the longest needle, should represent the most advanced evolutionary line (Gaussen 1964; Maheshwari and Biswas
1970). This opinion was recently confirmed by a phylogenetic study (Qiao et al. 2007).

The needle width (NW and $\mathrm{NH}$ ) was reported as 1-1.5 mm for all studied species (Vidaković 1991; Farjon 2010). We found the average values of these characters much smaller and discriminating among species at a statistically significant level (Table 2). 
Among all the other tested characters the VBH, DY, CD, NC, EH, HH, EW, HW, NS, NSC, PSCT, HS, PNVB and PNRC discriminated between compared species at a statistically significant level. This finding was confirmed in the Tukey's test and Kruskal-Wallis test for percentage PSCT, PSCI and PSCT three combinations, which additionally detected seven characters differentiating at least between two of three compared species (Table 2).

Our investigation did not confirm the occurrence of three layers of the hypodermis under epidermis and reduced cell lumen of epidermis within individuals of C. atlantica, reported by Gaussen (1964). We found only a single additional hypodermis layer at the angles of the needle cross-section and no difference in the epidermis cells of compared taxa. These differences might be resulting from brachyblast needles we analyzed, in contrast to Gaussen (1964) who probably analyzed the leaves of the long shoots. The same reason would explain the predominantly one resin canal detected in our study in contrast to two resin canals reported in all three cedar species studied.

The CD appeared discriminating at very high significance between $C$. brevifolia and both other species. This difference has not been described till now, similarly as different proportions of fibrous versus thin-walled cells around the resin canals (PSCF, PSCI and PSCT).

\section{Relations among species}

Analysis of discrimination on the individuals revealed, surprisingly, the highest level of distance between C. brevifolia and the two other compared cedars. No one individual of that species enters the $95 \%$ confidential area of individual dispersion neither for $C$. libani nor for C. atlantica, while the several individuals of the two latter are intermingling (Fig. 3a). This can indicate that needle morphological and anatomical characteristics allow distinguishing $100 \%$ of individuals of C. brevifolia from C. libani and $C$. atlantica, but not all individuals of C. libani from $C$. atlantica. The scatter-plot of discrimination analysis for population centroids of the three compared species also pointed out the high level of differences between $C$. brevifolia and populations of the two remaining species (Fig. 3b). The agglomeration on the shortest Euclidean distances among populations confirmed this result and, surprisingly, showed a stronger relation of C. brevifolia to geographically distant $C$. atlantica, than to C. libani (Fig. 3b). These results support rather the idea of the taxonomic position of $C$. brevifolia as a species (Farjon 2001). However, the population genetics and phylogenetic studies suggest a close or even very close relationship between $C$. brevifolia and C. libani (Scaltsoyiannes 1999: based on isoenzymes; Qiao et al. 2007: based on cpDNA and mtDNA sequences; Bou Dagher-Kharrat et al. 2007: based on AFLP markers). These former studies have shown that all taxa around the Mediterranean basin are subspecies of C. libani (Scaltsoyiannes 1999; Qiao et al. 2007; Bou Dagher-Kharrat et al. 2007). Only one study using a isoenzyme banding pattern indicated quite a high level of difference between $C$. libani and $C$. brevifolia (Panetsos et al. 1992). The close affiliation of $C$. brevifolia to C. libani was also detected in the karyotype analysis of the cedars (Bou Dagher-Kharrat et al. 2001).

The estimation of the divergence time of $C$. brevifolia from $C$. libani was proposed as before about 6 Mya (Qiao et al. 2007), which is approximated to the Messinian Salt Crisis time (Mai 1989; Krijgsman 2002; Hellwig 2004). When accepting this hypothesis, the Cypriote environmental conditions should influence the needle morphology, resulting in formation of different values of most of the characters (Tables 2, 3). The high level of genetic diversity detected within $C$. brevifolia can indicate the long-term presence of the species in the mountains of Cyprus (Bou Dagher-Kharrat et al. 2007; Eliades et al. 2011). The significant level of divergence among particular populations of the species is characteristic for the narrow endemics (e.g., Carrió et al. 2010; Eliades et al. 2011), and indicate their spatial isolation but also can be a signal of origin from a widespread ancestor (Eliades et al. 2011). The historical events, which could allow for direct contact between populations of Cypriote and Anatolian cedars taking place during the Miocene Messinian Salt Crisis, when the level of the Mediterranean Sea subsided forming several land bridges between the Asiatic continent and Cyprus (Pons and Quézel 1985; Thompson 2005). The cedar seeds from the various regions of continent, transported during that time by animals were the source of the remnant $C$. brevifolia population on the Cyprus (Eliades et al. 2011). The possible origin from different regions (Taurus, Antitaurus, Lebanon mountain ridges) can be also a reason for the high level of genetic variation of the species (Bou DagherKharrat et al. 2007; Eliades et al. 2011).

\section{Relationships among Cedrus libani populations}

The differences between Lebanese and Anatolian populations of $C$. libani were recently described based on isozyme and cpDNA investigations (Bou Dagher-Kharrat et al. 2007; Fady et al. 2008:93, Figs. 2, 3). The multivariate examination of the short shoot needle characteristics allow for detecting differentiation of the species to three groups of populations (Figs. 3b, 4). The detected morphological differentiation is partly similar to AFLP-based genetic differentiation of the species described by Bou DagherKharrat et al. (2007:280; Fig. 3). The geographically close populations from the same or very near mountain ridges appeared to be genetically more similar, than those coming 
from distant locations. Also a low level of differentiation among Lebanese populations based on the RAPDs markers (Semaan and Dodd 2008) confirm this assumption. The described pattern of genetic and morphological differentiation can result from adaptation to local environmental conditions of the three regions, but also can be, at least partly genetically conditioned. When the latter is true, the differences among the populations from the West Taurus, the Antitaurus and the Lebanon mountains can be conserved or even intensified due to lack of gene flow among them.

Acknowledgments The collection of the majority of the material used in the present study was made possible through bilateral cooperation between the Polish Academy of Sciences and the Consejo Superior de Investigaciones Científicas (Spain) and unofficial cooperation between the Institute of Dendrology and the Faculty of Forestry of Kahramanmaras Sutcu Imam University in Turkey. The study was partly sponsored by the Institute of Dendrology of the Polish Academy of Sciences. We are grateful to Samuel Pyke for correcting the English of a previous version of the manuscript.

Open Access This article is distributed under the terms of the Creative Commons Attribution License which permits any use, distribution, and reproduction in any medium, provided the original author(s) and the source are credited.

\section{References}

Blokhina NI, Afonin MA (2007) Fossil wood of Cedrus penzhinaensis sp. nov. (Pinaceae) from the Lower Cretaceous of northwestern Kamchatka (Russia). Acta Palaeobot 47:379-389

Boratyńska K, Bobowicz MA (2001) Pinus uncinata Ramond taxonomy based on needle characters. Pl Syst Evol 227:183-194

Boratyńska K, Boratyński A (2007) Taxonomic differences among closely related pines Pinus sylvestris, P. mugo, P. uncinata, $P$. rotundata and $P$. uliginosa as revealed in needle sclerenchyma cells. Flora 202:555-569

Boratyńska K, Lewandowska D (2009) Differences among three populations of Pinus uliginosa and their relation to P. sylvestris as expressed by the needle characters. Dendrobiol 61:37-46

Bou Dagher-Kharrat M, Grenier G, Bariteau M, Brown S, SilyakYakovlev S, Savouré A (2001) Karyotype analysis reveals interspecific differentiation in the genus Cedrus despite genome size and base composition constancy. Theor Appl Genet 103:846-854

Bou Dagher-Kharrat M, Mariette S, Lefèvre F, Fady B, Grenier-de March G, Plomion C, Savouré A (2007) Geographical diversity and genetic relationships among Cedrus species estimated by AFLP. Tree Genet Genom 3:275-285

Boydak M (2002) Regeneration of Lebanon cedar (Cedrus libani A.Rich.) on karstic lands in Turkey. For Ecol Manage 178:231-243

Browicz K (1982) Chorology of trees and shrubs in south-west Asia and adjacent regions 1. PAS, Warszawa

Brunetti M, De Capua EL, Macchioni N, Monachello S (2001) Natural durability, physical and mechanical properties of Atlas cedar (Cedrus atlantica Manetti) wood from Southern Italy. Ann For Sci 58:607-613
Carrió E, Forrest AD, Güemes J, Vargas P (2010) Evaluating species non-monophyly as a trait affecting genetic diversity: a case study of three endangered species of Antirrhinum L. (Scrophulariaceae). Plant Syst Evol 288:43-58

Charco J (2001) Guía de los árboles y arbustos del Norte de África. Agencia Española de Cooperación International, Madrid

Cheddadi R, Fady B, François L, Hajar L, Suc JP, Huang K, Demarteau M, Vendramin GG, Ortu E (2009) Putative glacial refugia of Cedrus atlantica deducted from Quaternary pollen records and modern genetic diversity. J Biog 36:1361-1371

Coode MJE, Cullen J (1965) Cedrus Link. In: Davis PH (ed) Flora of Turkey and the East Aegean Islands, 1. Edinburgh University Press, Edinburgh, pp 71-72

Dörken VM, Stützel T (2012) Morphology, anatomy and vasculature of leaves in Pinus (Pinaceae) and its evolutionary meaning. Flora 207:57-62

Eckenwalder JE (2009) Conifers of the world, the complete reference. Timber Press, London

Elenga H, Peyron O, Bonnefille R, Jolly D, Cheddadi R, Guiot J, Andrieu V, Bottema S, Buchet G, de Beaulieu JL, Hamilton AC, Maley J, Marchant R, Perez-Obiol R, Reille M, Riollet G, Scott L, Straka H, Taylor D, Van Campo E, Vincens A, Laarif F, Jonson H (2000) Pollen-based biome reconstruction for southern Europe and Africa 18,000 yrBP. J Biog 27:621-634

Eliades N-GH, Gailing O, Leinemann L, Fady B, Finkeldey R (2011) High genetic diversity and significant population structure in Cedrus brevifolia Henry, a narrow endemic Mediterranean tree from Cyprus. Pl Syst Evol 294:185-198

Fady B, Lefévre F, Reynaud M, Dagher-Kharrat MB, Vendramin GG, Anzidei M, Pastorelli R, Savouré A, Bariteau M (2003) Gene flow among different taxonomic units: evidence from nuclear and cytoplasmic markers in Cedrus plantation forests. Theor Appl Genet 107:1132-1138

Fady B, Lefévre F, Vendramin GG, Ambert A, Régnier C, Bariteau M (2008) Genetic consequences of past climate and human impact on eastern Mediterranean Cedrus libani forest. Implications for their conservation. Conserv Genet 9:85-95

Farjon A (2001) World checklist and bibliography of conifers, vol 3, 2nd edn. Royal Botanic Gardens, Kew

Farjon A (2010) A handbook of the world's conifers. Brill, LeidenBoston

Ferguson DK (1967) On the phytogeography of coniferales in the European Cenozoic. Plaeogeogr Plaeoclim Plaeoecol 3:73-110

Frankis MP (2000) Cedrus Trew. In: Güner A, Özhatay N, Ekím T, Başer KHC (eds) Flora of Turkey and East Aegean Islands, vol 11. University Press, Edinburgh, pp 5-6

Gaussen H (1964) Genre Cedrus. Les Gymnospermes actuelles et fossiles 7:295-320

Greuter W, Burdet HM, Lang G (1984) Med-Checklist 1. Conservatoire et Jardin Botanique de la ville de Gevéve, Genéve

Hellwig FHA (2004) Centaureinae (Asteraceae) in the Mediterranean history of ecogeographical radiation. Pl Syst Evol 246:137-162

Ivanov D, Utescher T, Mosbrugger V, Syabryaj S, DjordjevićMilutinović D, Molchanov S (2011) Miocene vegetation and climate dynamics in Eastern and Central Paratethys (Southeastern Europe). Palaeogeogr Palaeoclim Palaeoecol 304:262-275

Khuri S, Shmoury MR, Baalbaki R, Maunder M, Talhouk SN (2000) Conservation of the Cedrus libani populations in Lebanon: history, current status and experimental application of somatic embryogenesis. Biodivers Conserv 9:1261-1273

Krijgsman W (2002) The Mediterranean: mare nostrum of Earth sciences. Earth Planet Sci Lett 205:1-12

Krüssmann G (1985) Manual of cultivated conifers, 2nd edn. Timber Press, Portland 
Magri D, Parra I (2002) Late quaternary western Mediterranean pollen records and African winds. Earth Planet Sci Lett 200:401-408

Maheshwari P, Biswas Ch (1970) Monogr 54:1-115 Council of Cientific et Industrial Research, New Delhi

Mai DHZ (1989) Development and regional differentiation of the European vegetation during the Tertiary. Pl Syst Evol 162:79-91

Manzi G, Magri D, Palombo MR (2011) Early-Middle Pleistocene environmental changes and human evolution in the Italian Peninsula. Quat Sci Rev 30:1420-1438

Marin M, Koko V, Duletić-Laušević S, Marin PD (2009) Effect of air pollution on needles of Cedrus atlantica (Endl.) Carriere in industrial area of Pančevo (Serbia). Bot Serb 33:69-73

Meikle RD (1977) Flora of Cyprus. Royal Botanic Gardens, Kew

Page CN (1990) Pinaceae. In: Kramer K.U. and Green P.S. eds. Pteridopgytes and Gymnospersms. In: Kubitzki K (ed) The families and genera of vascular plants, 1. Springer, Barcelona, pp 319-331

Panetsos KP, Christou A, Scaltsoyiannes A (1992) First analysis on allozyme variation in cedar species (Cedrus sp.). Silvae Genet 41:339-341

Pons A (1998) L'histoire du genre Cedrus d'aprés les données paléobotaniques disponibles. For Méditerr 19:236-242

Pons A, Quézel P (1985) The history of the flora and vegetation and past and prezent human disturbance in the Mediterranean region. In: Gomez-Campo C (ed) Plant conservation in the Mediterranean area. Junk Publishers, Dortreht, pp 25-43

Postigo-Mijarra JM, Morla C, Barrón E, Morales-Molino C, García S (2010) Patterns of extinction and persistence of Arctotertiary flora in Iberia during the Quaternary. Rev Palaeobot Palynol 162:416-426

Qiao C-Y, Ran J-H, Li Y, Wang X-Q (2007) Phylogeny and biogeography of Cedrus (Pinaceae) inferred from sequences of seven paternal chloroplast and material mitochondrial DNA regions. Ann Bot 100:573-580

Ruzin SE (1999) Plant microtechnique and microscopy. Oxford University Press, Oxford

Sattout EJ, Talhouk SN, Caligari PDS (2007) Economic value of cedar relics in Lebanon: an application of contingent valuation method for conservation. Ecol Econom 61:315-322
Scaltsoyiannes A (1999) Allozyme differentiation and phylogeny of cedar species. Silvae Genet 48(2):61-68

Semaan MT, Dodd RS (2008) Genetic variability and structure of the remnant natural populations of Cedrus libani (Pinaceae) of Lebanon. Tree Genet Genomes. doi:10.1007/s11295-008-0148-y

Sękiewicz K, Sękiewicz M, Jasińska AK, Boratyńska K, Iszkuło G, Romo A, Boratyński A (2012) Morphological diversity and structure of West Mediterranean Abies species. Pl Biosyst (in print)

Sokal RR, Rohlf TJ (1997) Biometry: the principles and practice of statistics in biological research. Freeman W. H. \& Comp, San Francisco

Stanisz A (2007) Przystępny kurs statystyki, 2. StatSoft, Kraków

Svenning JC (2003) Deterministic Plio-Pleistocene extinctions in the European cool-temperate tree flora. Ecol Lett 6:646-653

Tabachnik BG, Fidell LS (1996) Using multivariate statistics. Harper Collins College Publishers, New York

Terrab A, Paun O, Talavera S, Tremetsberger K, Arista M, Stuessy TF (2006) Genetic diversity and population structure in natural populations of Moroccan Atlas cedar (Cedrus atlantica, Pinaceae) determined with cpSSR markers. Am J Bot 93:1274-1280

Terrab A, Hampe A, Lepais O, Talavera S, Vela E, Stuessy TF (2008) Phylogeography of North African Atlas cedar (Cedrus atlantica, Pinaceae): combined molecular and fossil data reveal a complex Quaternary history. Am J Bot 95:1262-1269

Thompson JD (2005) Plant evolution in the Mediterranean. Oxford University Press, Oxford

Utescher T, Djordjević-Milutović D, Bruch A, Mosbrugger V (2007) Palaeoclimate and vegetation change in Serbia during the last 30 Ma. Palaeogeogr Palaeoclimatol Palaeoecol 253:141-152

Velitzelos D, Kvaček Z, Velitzelos E (2000) Palaeoecological and climatological significance of conifer synusiae occurring in the Tertiary of Greece. Abstr 6th Conference IOP, Quinhuangdao, pp 137-138

Vidaković M (1991) Conifers. Graficki Zavod Hrvatske 